DOI https://doi.org/10.18551/rjoas.2021-02.14

\title{
FOOD SECURITY INDEX AND ADOPTION OF AGRICULTURAL TECHNOLOGIES AMONG SESAME FARMERS, ABUJA, NIGERIA
}

\author{
Alabi Olugbenga Omotayo* \\ Department of Agricultural Economics, University of Abuja, Gwagwalada-Abuja, Nigeria \\ ORCID: 0000-0002-8390-9775
}

Sunday Ajayi Godfrey

G-Consulting International Services Limited, Apo-Gudu, Abuja, Nigeria ORCID: 0000-0002-2792-9392

\section{Waziri-Ugwu Phidelia Ramatu}

Department of Agricultural Economics and Extension, Federal University Gashua, Gashua, Yobe State, Nigeria

ORCID: 0000-0003-1922-5122

Shaba Moses Gado

Department of Agricultural Economics, University of Abuja, Gwagwalada-Abuja, Nigeria

ORCID: 0000-0001-9820-5933

\author{
Emeghara Ursulla Ukamaka \\ Department of Crop Production, Federal College of Forestry Mechanization, \\ Forestry Research Institute of Nigeria, Kaduna, Kaduna State, Nigeria \\ ORCID: 0000-0003-3684-1525
}

\section{Omole Ebunlola Bosede}

Basic Science Department, Federal College of Wildlife Management, Forestry Research Institute of Nigeria, New Bussa, Niger State, Nigeria

ORCID: 0000-0001-8493-4190

\section{David Hyelni Seth}

Department of Agricultural Economics and Extension, Federal University Gashua, Gashua, Yobe State, Nigeria

ORCID: 0000-0003-2071-8821

\section{Olumuyiwa Samson Abiade}

Department of Basic Sciences and General Studies, Federal College of Forestry Mechanization, Forestry Research Institute of Nigeria, Kaduna, Kaduna State, Nigeria ORCID: 0000-0003-1596-1114

\section{Sanusi Saheed Olakunle}

Department of Agricultural Economics and Extension, Federal University Gashua, Gashua, Yobe State, Nigeria

ORCID: 0000-0002-0531-643X

\section{ABSTRACT}

This study evaluated food security index and adoption of agricultural technologies among sesame farmers in Abuja, Nigeria. The objectives specifically designed for this study were: determine the socio-economic profiles or characteristics of sesame farmers, evaluate the food security index of sesame farmers, determine the marginal productivity of sesame farmers, determine the adoption index of sesame farmers and evaluate factors influencing adoption of agricultural technologies among sesame farmers. Data used were of primary sources. Data were collected using well-designed and also well-structured questionnaire. 
The questionnaire was subjected to validity and reliability tests. Multi-stage sampling method was used to select 100 sesame farmers. Data were analyzed using the following statistical and econometric tools: descriptive statistics, food security index, marginal productivity, adoption index and Logit regression model. The results show that $70 \%$ of sesame farmers were less than 50 years which implies that they are young, active, energetic and resourceful. Also, $64 \%$ of sesame farmers were married and $90 \%$ of them had formal education. The household sizes were large with an average of 7 people per household. Sesame farmers had considerable experiences in farm activities with an average of 8 years experiences in sesame farming. Based on headcount ratio, 54\% of sesame farming households was food secure while $46 \%$ were food insecure. Two-third mean of per capital expenditure on food by sesame farming households was 1, 551.10 Naira Resource productivity shows that land, seed, and fertilizers were under-utilized while labour was over-utilized. An average adoption index of $72 \%$ was estimated and $47.37 \%$ of sesame farmers were medium adopters while $52.63 \%$ of sesame farmers were high adopters of agricultural technologies. Age $(\mathrm{P}<0.05)$, extension contact $(\mathrm{P}<0.10)$, educational level $(\mathrm{P}<0.05)$, access to credit facilities $(\mathrm{P}<$ $0.10)$, farming experiences $(\mathrm{P}<0.05)$, and farm income $(\mathrm{P}<0.05)$ were the statistical and significant factors influencing adoption of agricultural technologies among sesame farmers. The study recommends easy access to improved agricultural inputs such as improved seeds, fertilizers, labour input and land by sesame farmers and increased extension contact with sesame farmers in the area.

\section{KEY WORDS}

Food security, marginal productivity, adoption, agricultural technologies, Abuja, Nigeria.

Food security is one of the greatest challenge facing sub-Saharan African and the world (FAO, 2010). Agriculture has the potentials of reducing poverty, increasing food security and promoting economic development in sub-Saharan Africa. In Nigeria agricultural sector is very important in terms of its role in food security, poverty alleviation and growth of the economy (Maurice, Adamu and Joseph, 2014). Prices of food and agricultural commodities are increasing in Africa. USAID (1992) defined food security as situation people at all times have both economic and physical access to food sufficiently needed to meet their dietary needs for healthy and productive life. Food security is rooted in three pillars, they are food availability, food access and food utilization. Across the world, 800 million people go to bed hungry every night (FAO, 2019). Food insecurity is said to be rooted in poverty. In Nigeria, poverty is rising, more than 167 million Nigerians are living with less than $\$ 1$ a day. Poverty and food insecurity are of great concerns in sub-Saharan Africa, including Nigeria. The greatest challenge facing sub-Saharan Africa's agricultural sector is to increase production and the value of agricultural products. Food production in sub-Saharan African is faced with the problem of low crop yields and resource productivity. Agriculture in Nigeria is confronted with the problem of low productivity arising from inefficient use of available resources (Alabi, Oladele and Oladele, 2020; Udoh, 2005, Obasi and Agu, 2000).Increases in productivity and efficiencies in the agricultural sector are the most effective way for sustainable economic development. Increasing farm productivity and income of farmers arising from adoption of new agricultural technologies has received the attention of many policy makers and researchers. Improving agricultural productivity, efficiency with available technology and resource base, sustainable agricultural development can raise farm productivity. According to Amanza and Maurice (2005), Panda (2007) the change in food crop production include change in technique of production, change in productivity of inputs used, type of technology, and change in the hectares of land cultivated for various crops.

Fundamental way of increasing agricultural productivity is through the use of agricultural technologies (Obisesan, Amos and Akinlade, 2016). Farm resource productivity can be improved when farmers properly understand efficient use of resources and how to select farm enterprises. The core elements for sustainable crop production among smallholder farmers are resource use efficiency and productivity growth. Sustenance of production system can be achieved when farmers properly understand production efficiency 
arising from optimal use of inputs combined with the level of technology available. Agricultural productivity can be increased using improved agricultural technologies this will enhance sustainable food and fibre production which are critical issues for sustainable food security and economic development (Obayelu and Ajayi, 2018). Agricultural production technologies can be in terms of improved seed varieties, pesticides, planters and irrigation systems, fertilizers, recommended crop spacing, planting dates, harvesting dates amongst others. The key to global food security and poverty alleviation is increasing agricultural productivity. Improved and access to agricultural technologies and management practices are tools for enhancing agricultural productivity. Research and adoption of new technologies are issues in increasing agricultural productivity, also, the major factor in technology adoption is credit, and this can transform smallholder farmers into commercial scale (Abayomi and Salami, 2008). Rural credit for smallholder farmers will enhance adoption of agricultural technologies and increase agricultural production and productivity (Odoemenem and Obinne, 2010).

Sesame (Sesamum indicum $\mathrm{L}$ ) also called benniseed originated from tropical Africa. It is quality oil seed crop which contains $50 \%$ oil and $25 \%$ protein. Sesame can be used for food and oil. The oil can be used for cooking, baking, salad oil, margarine, and candy making. Sesame oil can be used for making paints, soaps, insecticides, perfumes, and pharmaceuticals. Sesame meal what is left after oil is extracted and pressed from the seed contains from 34 to $50 \%$ protein used for poultry and livestock feeds (Oplinger et al, 2007, Nwalem, 2015).Sesame is becoming prominent among Nigeria non-oil agricultural export crops coming second after cocoa. Nigeria has an opportunity to earn foreign exchange by increasing sesame production to meet international demand for the agricultural commodity. In Nigeria, sesame is cultivated in Northern states over 80,000 hectares of land. In 2010, Nigeria exported 140,800 tonnes of sesame seeds. Major sesame producing Countries were India, Ethiopia, Uganda, Nigeria, Sudan, China, and Burma (Myanmar). Africa grows $26 \%$ of world sesame (Hassen, 2011).

The broad objective is to evaluate food security index and adoption of agricultural technologies among sesame farmers in Abuja, Nigeria. The objectives specifically designed for this research study were:

- Determine the socio-economic profiles or characteristics of sesame farmers;

- Evaluate food security index of sesame farmers;

- Determine the marginal productivity of sesame farmers;

- Determine the adoption index of sesame farmers;

- Evaluate factors influencing adoption of agricultural technologies among sesame farmers.

\section{METHODS OF RESEARCH}

The research study was conducted in Abuja, Nigeria. Abuja lies between Latitudes $9^{0}$ $4^{\prime} 20^{\prime \prime}$ North and the Longitudes $7^{\circ} 29^{\prime} 28^{\prime \prime}$ East. In Abuja, there are rainy and dry seasons, in between these seasons we have brief harmattan period. The rainy season starts from March to October. The temperature varies from $28^{\circ} \mathrm{C}$ to $40^{\circ} \mathrm{C}$. It has an area of 8,000 Square $\mathrm{Km}$. The population of Abuja according to NPC (2006) is about 776, 298 people. Agriculture is the main occupation of the inhabitant of Abuja. They are involved in growing crops and animal production. Crops grown include millet, sesame, sorghum, garden egg, yam, cowpea, rice, groundnut amongst others. Animal kept include goats, poultry, sheeps, rabbit, turkey, and cattle.

Primary data were used. Data from primary sources were obtained with the use of questionnaire. The questionnaire was well-designed and well-structured to answer the objectives of the research study. The questionnaire was subjected to validity and reliability tests. Multi-stage sampling method was used for this research study. First stage, involve simple random selection of Abuja using ballot-box raffle draw method. Second, third and fourth stages involve simple random selection of one area council, 5 wards and 5 villages 
using ballot-box raffle draw method respectively. Fifth and final stage involves proportional random selection of 100 sesame farmers using Yamane (1967) equations of estimating sample size. Yamane (1967) formula for calculating sample size is stated thus:

$$
n=\frac{N}{1+N(e)^{2}}=100
$$

Where: $n=$ Sample Size (Units); N = Sample Frame (Units); e=Level of Precision (10\%).

The statistical and econometric tools used for data analysis include:

Descriptive Statistics involves the use of frequency distributions, mean, and percentages to have summary descriptions of data collected. This was used to achieve specific objective one (i).

The Food Security Model for sesame farmers following Omonona et al (2007) is stated thus:

$$
F_{i}=\frac{\text { Per Capital Expenditure for the Sasame Farmers }}{\frac{2}{3} \text { Mean Per Capital Food Expenditure of all Households }}
$$

Where: $F_{i}=$ Food Security Index; $F_{i} \geq 1=$ Food Secure for ith Household; $F_{i}<1=$ Food Insecure for ith Household.

The Headcount Index formular is stated thus:

$$
\text { Headcount Index }(H)=\frac{M}{N}
$$

Where: $\mathrm{M}=$ Number of Food Secure/Insecure Households (Units); N = Number of Household in the Sample (Units).

This was used to answer specific objective two (ii).

Marginal Productivity Index according to Alabi, Oladele and Oladele (2020) is stated thus:

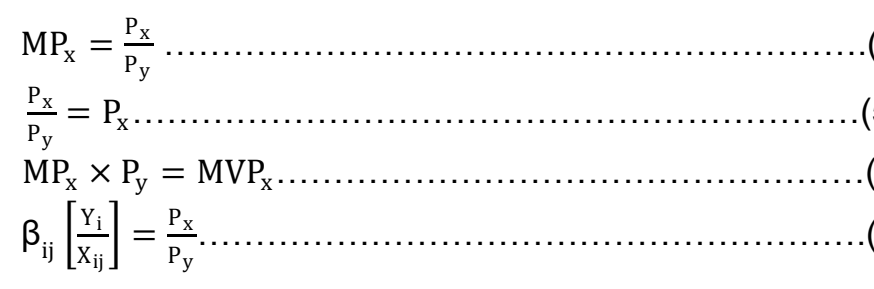

Where:

$\mathrm{P}_{\mathrm{x}}=$ Unit Cost of Each Resources Employed (Naira);

$\mathrm{P}_{\mathrm{y}}=$ Price of Output (Naira);

$\mathrm{MVP}_{\mathrm{x}}=$ Marginal Value Product of $x$;

$\mathrm{MP}_{\mathrm{x}}=$ Marginal Productivity of $x$;

$\beta_{\mathrm{ij}}=$ Elasticities of Inputs;

$\beta_{\mathrm{ij}}\left[\frac{\mathrm{Y}_{\mathrm{i}}}{\mathrm{X}_{\mathrm{ij}}}\right]=$ Marginal Product $\left(\mathrm{MP}_{\mathrm{x}}\right)$ of the Input.

$$
\begin{aligned}
& M_{P_{x}}>P_{x}=\text { Under Utilization of Input } \\
& M_{x}<P_{x}=\text { Over Utilization of Input... } \\
& M_{P_{x}}=P_{x}=\text { Optimum Input Utilization }
\end{aligned}
$$

This was used to answer specific objective three (iii).

Adoption Index (Al) following Dongol (2004), Dhital and Joshi (2016) are stated thus:

$$
\mathrm{AI}=\frac{\mathrm{TAF}}{\mathrm{MSF}} \times 100
$$


Where: $\mathrm{AI}=$ Adoption Index (Units); $\mathrm{TAF}=$ Total Adoption Score for ith Sesame Farmers (Units); MSF = Maximum Adoption Score Sesame Farmers can obtain (Units).

$$
\mathrm{AAI}=\frac{\sum_{i}^{n} \mathrm{AI}}{\mathrm{N}}
$$

Where: AAI =Average Adoption Index (Units); N= Number of Sesame Farmers (Units).

High Adopters have adoption index higher, above or equal to Average Adoption Index (AAI), Medium Adopters have Adoption Index below the Average Adoption Index (AAI).This will be used to achieve specific objective four (iv).

The Logit regression model is stated thus:

$$
Y_{i}=\alpha_{0}+\sum_{i=1}^{6} \alpha_{i} X_{i}+U_{i}
$$

The explicit function is stated thus:

$$
Y_{i}=\alpha_{0}+\alpha_{1} X_{1}+\alpha_{2} X_{2}+\alpha_{3} X_{3}+\alpha_{4} X_{4}+\alpha_{5} X_{5}+\alpha_{6} X_{6}++U_{i}
$$

Where:

$Y_{i}=$ Dichotomous Response of Technology Adoption (1, High Adopters ; 0, Otherwise);

$X_{1}=$ Age of Sesame Farmers (Years);

$X_{2}=$ Extension Contact (1, Access; 0, Otherwise);

$X_{3}=$ Educational Level (Number of Years in in School);

$X_{4}=$ Access to Credit Dummy (1, Access; 0, Otherwise);

$X_{5}=$ Farming Experience (Years);

$X_{6}=$ Farm Income (Naira);

$U_{i}=$ Error Term;

$\alpha_{0}=$ Constant Term;

$\alpha_{1}-\alpha_{6}=$ Regression Coefficients;

This was used to achieve specific objective five (v).

\section{RESULTS AND DISCUSSION}

Socio-Economic Profiles of Sesame Farmers. Table 1 presented the socio-economic profiles of sesame farmers. About $70 \%$ of sesame farmers were less than 50 years of age. The mean age of sesame farmers was 46 years. This means that sesame farmers were active, young, energetic and resourceful. Sesame farmers will be able to adopt innovations, research findings and new technologies. Also, 64\% of sesame farmers were married and $91 \%$ had formal education. Education of farmers is important for adoption of new technologies among sesame farmers. The household sizes were large, $98 \%$ of sesame farmers had less than 16 people as household members. The mean experience of sesame farmers in farm activities was 8 years. Furthermore, $63 \%$ of sesame farmers had less than 11 years experiences in farm activities. This result is in line with results of Alabi, Coker, Adeola and Maduekwe (2010), Alabi, Lawal and Oladele (2016), Obisesan, Amos and Akinlade (2016), Tukura and Ashindo (2019), Sidi, Damisa, Yusuf and Oladimeji (2014) who reported in their research findings that sesame farmers were active, young and resourceful.

Sesame farming households were profiled into food secure and food insecure groups using their per capital food expenditure as presented in Table 2. The food insecurity line was defined by the two-third of the mean per capital of food expenditure of the sesame farming household head. According to Omonona et al (2007) sesame farming household is considered food secure if it attained minimum of two-third of the mean per capital expenditure on food per month. Sesame farmers that spent at least 1,551.10 Naira on food per month were grouped as food secure, and those sesame farming households that spent 
less than 1, 551.10 Naira per month were grouped as food insecure. This implies that for sesame farmers to be considered as food secure, they must spend 51.70 Naira per day. Based on the headcount ratio presented in Table 2, about $54 \%$ of sesame farmers had their monthly per capital expenditure on food higher or equal to 1, 551.10 Naira, while $46 \%$ of the sesame households had their monthly per capital food expenditure less than 1,551.10 Naira. The mean monthly per capital expenditure of the food secured sesame farmers was $3,321.11$ Naira, a food secured sesame farming households spend on the average about 110.70 Naira per day. Also, food insecure sesame farming households spend on the average of $1,134.07$ Naira per month and 37.80 Naira per day. This result is in line with findings of lorlamen et al (2014), Olabisi and Olarewamiwa (2014) who observed in their research studies that $51 \%$ of rural farmers in sub-Saharan Africa were food secure.

Table 1 - Socio-Economic Profiles of Sesame Farmers

\begin{tabular}{llll}
\hline Socio-Economics Profiles & Frequency & Percentages & Mean \\
\hline Sex & 55 & & \\
Male & 45 & 55.00 & \\
Female & & 45.00 & \\
Age (Years) & 34 & 34.00 & 46.00 \\
$31-40$ & 36 & 36.00 & \\
$41-50$ & 21 & 21.00 & \\
$51-60$ & 09 & 09.00 & \\
$>60$ & & & \\
Marital Status & 36 & 36.00 & \\
Single & 64 & 64.00 & \\
Married & & & \\
Level of Education & & 32.00 & \\
Primary & 32 & 39.00 & \\
Secondary & 39 & 20.00 & \\
Tertiary & 20 & 09.00 & \\
Non-Formal & 09 & & \\
Household Size (Units) & & 36.00 & 7.55 \\
$1-5$ & 36 & 39.00 & \\
$6-10$ & 39 & 23.00 & \\
$11-15$ & 23 & 02.00 & \\
$16-20$ & 02 & & \\
Farm Experience (Years) & & 27.00 & 8.80 \\
$1-5$ & 27 & 36.00 & \\
$6-10$ & 36 & 31.00 & \\
$11-15$ & 31 & 06.00 & \\
$16-20$ & 06 & 100.00 & \\
Total & 100.00 & & \\
\hline
\end{tabular}

Source: Field Survey (2019) Computed Using STATA 14.

Table 2 - Food Security Index of Sesame Farmers

\begin{tabular}{llll}
\hline Food Security Index & Food Secure & Food Insecure & Total \\
\hline Percentage (\%) & 54.00 & 46.00 & 100 \\
Frequency & 54 & 46 & 100 \\
Monthly Expenditure on Food & & & \\
Sum (Naira) & $179,340.09$ & $52,167.52$ & $231,507.61$ \\
Mean (Naira) & $3,321.11$ & $1,134.07$ & $2,315.07$ \\
Headcount Ratio (H) & 0.54 & 0.46 & \\
\hline 2/3 Mean per Capital Food Expenditure was A $1,551.10$ & & \\
\hline
\end{tabular}

Source: Field Survey (2019), Computed using STATA 14.

The resources that were considered in this research study for sesame productivity were land, labour, seeds and fertilizers (Table 3). The marginal productivities of land, labour, seeds and fertilizers were $12.47,02.39,15.67$ and 17.20 respectively. The marginal value productivities of land, seeds and fertilizers were 275, 424; 221, 301 and 201, 500 respectively and were greater than their respective marginal factor cost and were therefore 
resources under-utilized. The marginal productivity of labour was 2,789 less than its marginal factor cost, therefore labour was over-utilized. This is line with result of Alabi, Oladele and Oladele (2020) who reported in their research results that land, seeds and fertilizers were under-utilized.

Table 3 - Marginal Productivity Index of Sesame Farmers

\begin{tabular}{lllll}
\hline Variable Input & \multicolumn{1}{c}{$\mathrm{MP}_{\mathrm{X}}$} & \multicolumn{1}{c}{$\mathrm{MVP}_{\mathrm{X}}$} & \multicolumn{1}{c}{$\mathrm{MFC}$} & \multicolumn{1}{c}{ Decision } \\
\hline Land & 12.47 & 275,424 & 15,200 & Underutilization \\
Labour & 02.39 & 2,789 & 3,500 & Overutilization \\
Seed & 15.67 & 221,301 & 3,000 & Underutilization \\
Fertilizer & 17.20 & 201,500 & 7,200 & Underutilization \\
\hline
\end{tabular}

Source: Field Survey (2019), Computed using STATA 14.

The average adoption index of sesame farmers was $72.0 \%$ (Table 4 ). About $47.37 \%$ of sesame farmers had their adoption indexes less than average adoption index. Also, $52.63 \%$ of sesame farmers had their indexes greater or equal to the average adoption index. This result is in line with findings of Dhital and Joshi (2016), Alabi (2016) who reported in their findings that $76 \%$ of sampled farmers were high adopters of agricultural technologies.

Table 4 - Adoption Index of Sesame Farmers

\begin{tabular}{lcl}
\hline Adopters & Average Adoption Index & Percentage \\
\hline Medium Adopters & $\leq 72 \%$ & 47.37 \\
High Adopters & $>72 \%$ & 52.63 \\
Total & & 100.00 \\
\hline
\end{tabular}

Source: Field Survey (2019), Computed using STATA 14.

Factors Influencing Adoption of Agricultural Technologies by Sesame Farmers. The statically and significant predictor variables included in the Logit model were age $(P<0.05)$, extension contact $(P<0.10)$, educational level $(P<0.05)$, access to credit facilities $(P<$ $0.10)$, farming experience $(P<0.05)$, and farm income $(P<0.05)$. The Wald Chi square of 162.70 was significant at $1 \%$ probability level. The Pseudo $R^{2}$ was 0.7901 this implies that the predictive power and overall explanatory power of $79.01 \%$ are quite high. The coefficient of level of education was positive. The marginal effects of educational level of sesame farmers show that as sesame farmers acquired formal education by one year, there would be $21.29 \%$ probability or likelihood that sesame farmers be higher adopters of agricultural technologies. This result is in line with findings of Alabi, Coker, Adeola and Maduekwe (2010), Kattel (2009).

Table 5 - Factors Influencing Adoption of Agricultural Technologies by Sesame Farmers

\begin{tabular}{llll}
\hline Variables & Coefficients & $\begin{array}{l}\text { Standard } \\
\text { Error }\end{array}$ & $\begin{array}{l}\text { Marginal } \\
\text { Effects }\end{array}$ \\
\hline Age $\left(X_{1}\right)$ & $0.2638^{* *}$ & 0.1055 & 0.1321 \\
Extension Contact $\left(X_{2}\right)$ & $0.3379^{*}$ & 0.1609 & 0.1520 \\
Educational Level $\left(X_{3}\right)$ & $0.4501^{\star *}$ & 0.1731 & 0.2129 \\
Access to Credit Facilities $\left(X_{4}\right)$ & $0.1289^{*}$ & 0.0585 & 0.3102 \\
Farming Experience $\left(X_{5}\right)$ & $0.3782^{* *}$ & 0.1400 & 0.2109 \\
Farm Income $\left(X_{6}\right)$ & $0.4102^{\star *}$ & 0.1525 & 0.1302 \\
Constant & $0.1332^{*}$ & 0.0605 & 0.1129 \\
Diagnose Statistics $\quad 162.70$ & & \\
$\quad$ Wald ${ }^{2}$ & 0.0000 & & \\
$\quad$ Prob $>{ }^{2}$ & 0.7901 & & \\
Pseudo $>R^{2}$ & 100 & & \\
Number of Observations & & & \\
\hline
\end{tabular}

Source: Field Survey (2019), Computed using STATA 14.

${ }^{*},{ }^{* *},{ }^{* *}$-Significant at 10\%, 5\% and $1 \%$ Probability Levels. 
Farming experience was found to have positive coefficient, statistical and significantly influence the probability and likelihood of higher adoption of agricultural technology by sesame farmers increases by $21.09 \%$. Sesame farmers using past experiences will have better control of the risk involved in farming activities. This result is in line with findings of Kavia et al (2007) who reported that socio-economic factors influence adoption of agricultural technologies among rural farmers. A significant and positive influence of contact with extension agent was also found. Sesame farmers frequent contact with extension officers will $15.20 \%$ increase the probability or likelihood to be higher adopters of agricultural technologies.

\section{CONCLUSION}

Sasame (Sesamum indicum $\mathrm{L}$ ) production was profitable in the area. The farmers were young, resourceful, active and energetic with an average age of 46 years. They were mostly literate with large household members. The average household size of 7 people per household was recorded.

The farmers had considerable experiences with an average of 8 years in sesame farming. Headcount ratio of sesame farming household shows that $54 \%$ of them were food secure while $46 \%$ were food insecure. Two-third mean per capital expenditure on food by sesame farmers was 1, 551.10 Naira. About $54 \%$ of sesame food secured farming household will spend on the average at least 1,551.10 Naira on food monthly and at least 51.70 Naira daily expenditures on food. The mean monthly expenditures for food insecurity index for sesame farming households was 1,134.07 Naira Marginal productivity index revealed that land, seed and fertilizers were under-utilized, while labour was over-utilized. The average adoption index for sesame farmers was $72 \%$. About $52.63 \%$ were high adopters of agricultural technologies while $47.37 \%$ were medium adopters of agricultural technologies. The statistical and significant factors influencing adoption of agricultural technologies by sesame farmers were age, extension contact, educational level, access to credit facilities, farming experiences and farm income.

\section{RECOMMENDATIONS}

The following policy recommendations were made based on the outcome of this research study:

- Farm inputs should be made available to sesame farmers such as improved seeds, fertilizers, chemicals, tractors, and equipments;

- Extension officers should be employed to disseminate research findings from research institutions to sesame farmers;

- Credit facilities at low interest rates should be made available to sesame farmers;

- Appropriate prices of sesame produce should be made available to farmers for good and reasonable profit margin;

- Access to information on agricultural technologies and capacity building should be made available to sesame farmers.

\section{REFERENCES}

1. Abayomi, S and Salami, O.A (2008). Impact of Commercial Bank Lending on Agricultural Production and Productivity in Nigeria. Journal of Agriculture, Food, Water and Drugs 2(1): $23-30$.

2. Alabi,O.O, Oladele, A.O, and Oladele,N.O (2020).Economic Market Decisions among Marginal Maize Farmers in Abuja, Nigeria: Applications of Double-Hurdle Model and Factor Analysis. Russian Journal of Agricultural and Socio-Economic Sciences (RJOAS) 8 (104): $114-125$.

3. Alabi, O.O.;Coker,A.A;Adeola,S.S and Maduekwe,I (2010). Technical Efficiency in Sesame Production in Nassarawa Doma Local Government Area of Nassarawa State, 
Nigeria: An Application of Stochastic Frontier Model, International Journal of Agriculture and Rural Development 1(2):115-121.

4. Alabi,O.O; Lawal, A.F and Oladele,A.O (2016). Factors Influencing the Use of Productivity Enhancing Technologies among Crop Farmers in Abuja, Nigeria. Journal of Sustainable Development in Africa (JSD-Africa) Clarion University of Pennsylvania USA 18(1): $40-52$.

5. Alabi,O.O. (2016). Adoption of Information and Communication Technologies (ICTs) by Agricultural Science and Extension Teachers in Abuja, Nigeria. American Journal of Agriculture and Education (JAE) USA, 57(1):137-149.

6. Amanza, P.S and Maurice, D.C (2005). Identification of Factors that Influence Technical Efficiency in Rice-Based Production Systems in Nigeria. (P. Kormawa and A. A.Toure (eds). Proceedings of a Workshop on Rice Policy and Food Security in Sub-Saharan Africa held in Cotonou, Benin, $7^{\text {th }}-9^{\text {th }}$ November, Pp $70-81$.

7. Dhital, P.R and Joshi, N.R (2016). Factors Affecting Adoption of Recommended Cauliflower Production Technology in Nepal. Turkish Journal of Agriculture, Food Science and Technology 4 (5): $378-383$.

8. Dongol, B.B.S (2004). Extension Education. Kathmandu, Nepal: Pratibha Singh Dongol.

9. FAO (2010). The State of Food Insecurity in the World. Food and Agriculture Organization (FAO) Report, Rome.

10. FAO (2019). Global Hunger Continues to Rise, New UN Report.

11. Hassen, R (2011). Sesame Profile. Available at http://www.agmrc.org/

12. Iorlamen, T.R.,Abu, G.A and Lawal, W.L (2014). Comparative Analysis on SocioEconomic Factors between Food Secure and Food Insecure Households among Urban Households in Benue State, Nigeria Journal of Agricultural Science 4 (20): 63 - 68.

13. Kattel, R.R (2009). The Impact of Coffee Production on Nepali Smallholders in the Value Chain (Unpublished). Institute of Environmental Economics and World Trade. Leibniz Universitat Hannover, Germany.

14. Kavia, F.Y.,Mushongi,C.C and Sonda, G.B (2007). Factors Affecting Adoption of Cassava Varieties: A Case of Cassava Mosaic Disease Tolerant Varieties in Lake Zone Regions-Tanzania. Proceedings of African Crop Science Conference, African Crop Science Society: 8.

15. Maurice, D.C., Adamu, Y and Joseph, M (2014). Analysis of Cost Efficiency in Food Crop Production among Smallscale Farmers in Adamawa State, Nigeria. Global Journal of Agriculture Sciences 14: $17-25$.

16. Nwalem, M.P (2015). Relationship between Level of Adverse Effect of Perceived Dimensions of Climate Change Manifestations and Production Efficiency among Sesame Farmers in Benue State, Nigeria. M.Sc Thesis Submitted to the Department of Agricultural Economics, University of Agriculture, Makurdi, Benue State, Nigeria.

17. NPC (2006). National Population Commission of Nigeria, Population Census, 2006.

18. Obayelu, A.E and Ajayi, D.O (2018). Economic Impact and Determinants of Adoption of Improved Maize Production Technologies. Journal of Agricultural Sciences 63 (2): 217 228.

19. Obasi, F.C and Agu, S.E (2000). Economics of Smallscale Rice Farming under Different Production Systems in South Eastern Nigeria. J Agric Business Rural Develop 1: 2.

20. Obisesan, A, A., Amos, T.T and Akinlade, R.J (2016).Causal Effect of Credit and Technology Adoption on Farm Output and Income: The Case of Cassava Farmers in Southwest Nigeria. $5^{\text {th }}$ International Conference of African Association of Agricultural Economists, Addis Ababa, Ethiopia, September 23 - 26, 2016.

21. Odoemenem, I.U and C.P.O Obinne (2010). Assessing the Factors Influencing the Utilization of Improved Cereal Crop Production Technologies by Smallscale Farmers in Nigeria. http:// www.indjust.org/archive/vol.3.issue.2/innocent-17.pdf

22. Olabisi, A.F and Olawamiwa, R.A (2014). Gender Dimensions of Food Security Status of Households in Oyo State, Nigeria. Global Journal of Human Social Science Research Vol 14 No $1-\mathrm{H}$. 
23. Oplinger, E.S., Putnam, D.H., Kaminski A.R., Hanson, C.V, Oelke, E.A., Schulte, E.E and Doll, J.D (2007). Alternative Field Crops Mannual: Sesame Retrieved: http://www.hort.purdue.edu/newcrop/afcm/sesame.html

24. Omonona, B.T.; Agoi, G.A. (2007). An Analysis of Food Security Situation among Nigeria Households: Evidence from Lagos State, Nigeria. Journal of Central European Agriculture, 8 (3): $397-406$.

25. Panda, S.C (2007). Farm Management and Agricultural Marketing. Kalyani Publishers, India 26-80.

26. Sidi, A.G., Damisa,.M.A., Yusuf, O and Oladimeji, Y.U (2014). Value Chain Analysis of Sesame in Bade and Jakusco Local Governement Areas of Yobe State, Nigeria. International Journal of Economics Development Research and Investment 5 (3) $39-51$.

27. Tukura, R.D and Ashindo,Z.E (2019). Determinants of Technical Efficiency of Sesame Production in Kurmi Local Government Area of Taraba State, Nigeria. IOSR Journal of Agriculture and Veterinary Science 12 (5): $43-51$.

28. Udoh, E.J (2005). Technical Inefficiency in Vegetable Farms of Humid Region: An Analysis of Dry Season by Urban Women in South-South Zone, Nigeria. J. Agric. Soc. Sci, $180-85$.

29. USAID (1992). United States Agency for International Development. Annual Report.

30. Yamane, T (1967). Statistics: An Introductory Analysis. $2^{\text {nd }}$ Edition, New York, Harper and Row Publishers. 